\title{
The limits of seaward spreading and slope instability at the continental margin offshore Mt Etna, imaged by high-resolution 2D seismic data
}

\author{
Felix Gross ${ }^{\mathrm{a}, \mathrm{b}, *}$, Sebastian Krastel ${ }^{\mathrm{b}}$, Jacob Geersen ${ }^{\mathrm{a}}$, Jan Hinrich Behrmann ${ }^{\mathrm{a}}$, Domenico Ridente ${ }^{\mathrm{c}}$, \\ Francesco Latino Chiocci ${ }^{\mathrm{d}}$, Jörg Bialas ${ }^{\mathrm{a}}$, Cord Papenberg ${ }^{\mathrm{a}}$, Deniz Cukur ${ }^{\mathrm{b}, 1}$, Morelia Urlaub ${ }^{\mathrm{a}}$, Aaron Micallef ${ }^{\mathrm{e}}$ \\ a GEOMAR - Helmholtz-Zentrum für Ozeanforschung Kiel, Wischhofstr. 1-3, 24148 Kiel, Germany \\ b Christian-Albrechts-Universität zu Kiel, Institut für Geowissenschaften, Otto-Hahn-Platz 1, 24118 Kiel, Germany \\ c IGAG-CNR, National Research Council, Rome, Italy \\ d Sapienza Università di Roma, P.le Aldo Moro 5, 00185 Rome, Italy \\ e Department of Physics, University of Malta, Msida, MSD 2080, Malta
}

\section{A R T I C L E I N F O}

Article history:

Received 13 February 2015

Received in revised form 8 November 2015

Accepted 11 November 2015

Available online 26 November 2015

\section{Keywords:}

Mt Etna

Flank instability

Continental margin

Tectonics

Spreading

Reflection seismics

\begin{abstract}
A B S T R A C T
Mount Etna is the largest active volcano in Europe. Instability of its eastern flank is well documented onshore, and continuously monitored by geodetic and InSAR measurements. Little is known, however, about the offshore extension of the eastern volcano flank, defining a serious shortcoming in stability models. In order to better constrain the active tectonics of the continental margin offshore the eastern flank of the volcano, we acquired a new high-resolution $2 \mathrm{D}$ reflection seismic dataset. The data provide new insights into the heterogeneous geology and tectonics at the continental margin offshore Mt Etna. The submarine realm is characterized by different blocks, which are controlled by local- and regional tectonics. A compressional regime is found at the toe of the continental margin, which is bound to a complex basin system. Both, the clear link between on- and offshore tectonic structures as well as the compressional regime at the easternmost flank edge, indicate a continental margin gravitational collapse as well as spreading to be present at Mt Etna. Moreover, we find evidence for the offshore southern boundary of the moving flank, which is identified as a right lateral oblique fault north of Catania Canyon. Our findings suggest a coupled volcano edifice/continental margin instability at Mt Etna, demonstrating first order linkage between on- and offshore tectonic processes.
\end{abstract}

(c) 2015 Elsevier B.V. All rights reserved.

\section{Introduction}

\subsection{Tectonic setting of Mt Etna}

Mt Etna, Europe's largest volcano, rises to a height of $3323 \mathrm{~m}$ (Fig. 1). The composite volcanic edifice sitting on top of continental crust (Gvirtzman and Nur, 1999) is highly active with an eruption history of 500 kyr (Branca and Del Carlo, 2004; Branca et al., 2004). Its recent volcanic unrest is documented by several eruptions per year during the last decades (Branca and Del Carlo, 2004).

Mt Etna's geological setting is characterized by the complex compressional tectonics of the Appenine-Maghrebian Fold and Thrust Belt

Abbreviations: AMTB, Appenine-Maghrebian Fold and Thrust Belt; CC, Catania Canyon; PPF, Pernicana-Provenzana Fault; RD, Riposto Depression; RR, Riposto Ridge; SFS, Southern Fault System; TFS, Timpe Fault System; TP, Timpe Plateau; VdA, Valle di Archirafi.

* Corresponding author at: Christian-Albrechts-Universität zu Kiel, Institut für Geowissenschaften, Otto-Hahn-Platz 1, 24118 Kiel, Germany. Tel.: + 494318802113.

E-mail address: fgross@geophysik.uni-kiel.de (F. Gross).

1 Currently at Korea Institute of Geoscience and Mineral Resources (KIGAM), Petroleum and Marine Research Division, Daejeon 305-350, Republic of Korea. to the south (Fig. 1), and the northwest dipping Calabrian subduction zone to the southeast (e.g., Doglioni et al., 2001). The Malta Escarpment (Fig. 1) represents a prominent northward trending escarpment in the Ionian Sea that can be traced southwards to the East of the Maltese Islands (Argnani and Bonazzi, 2005; Lentini et al., 2006). Representing an inherited weakness zone that causes a lithospheric tear between Ionian lithosphere and the continental lithosphere of the Hyblean Plateau, the Malta Escarpment largely affects the structural setting and subduction system underneath Calabria (Fig. 1) (e.g., Argnani and Bonazzi, 2005; Gvirtzman and Nur, 1999). Nevertheless, the nature and origin of the Ionian basin crust is still a matter of debate (e.g., Gallais et al., 2013; Polonia et al., 2012). Due to its regional importance as a deepseated weakness zone, a link between the Malta Escarpment and Mt Etna's edifice has been proposed, as the maximum uplift rates in the regional setting of Mt Etna are related to the upthrown side of the Malta Escarpment (Rust and Kershaw, 2000). However, the complex structure and morphology of the Timpe Plateau (Fig. 2) make it impossible to trace the Malta Escarpment as far north as Mt Etna (Argnani and Bonazzi, 2005; Nicolich et al., 2000).

Furthermore, recent interpretations based on refraction and reflection seismic data favor the existence of a distinct southeast trending 


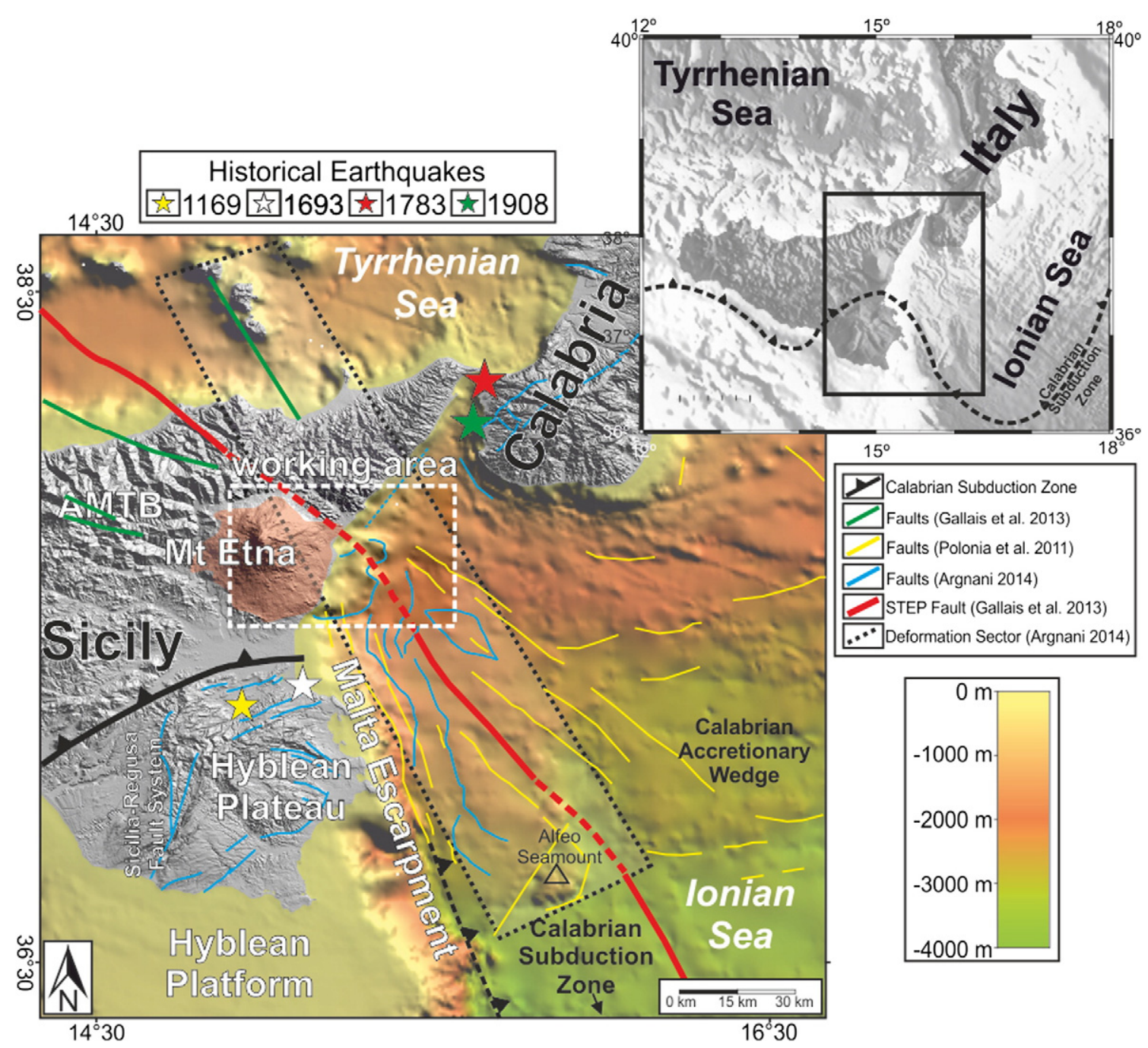

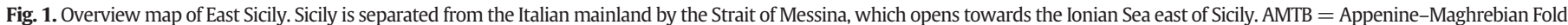
and Thrust Belt. The working area is marked by the dashed white box.

Subduction Transform Edge Propagator Fault (STEP-Fault), passing by Mt Etna's northern flank (Fig. 1) (Gallais et al., 2013, 2014; Musumeci et al., 2014; Polonia et al., 2012). Such a fault is required to delimit the retreating Calabrian subduction front towards the southwest, and to open an asthenospheric window at sub-lithosphere depths. The proposed STEP-fault is somewhat oblique to the Malta Escarpment (Fig. 1) (Gallais et al., 2013; Musumeci et al., 2014). Argnani (2014), however, does not find indications for a distinct near-surface STEP-fault in a dense grid of seismic lines from offshore eastern Sicily. Instead, he suggests a 20-30 km wide corridor of SSE trending faults (Fig. 1) affecting the entire area from Alfeo Seamount to Sicily to be the surface expression of a deep crustal-scale structure controlling the regional tectonics in this area. Argnani (2014) bases his interpretation on a series of asymmetric half-grabens, bound to eastward dipping normal faults (Argnani and Bonazzi, 2005; Bianca et al., 1999; Hirn et al., 1997; Nicolich et al., 2000). These normal faults are proposed to have generated earthquakes like the 1693 Catania event (Argnani et al., 2012; Bianca et al., 1999).
The entire region around Mt Etna is seismically highly active. Large earthquakes such as the disastrous Messina 1908 event (e.g., Pino et al., 2009) occurred in the Strait of Messina north of Mt Etna. Furthermore, deep (20-30 km) compressive earthquakes, probably related to thrusting in the Appennine-Maghrebian Thrust Belt, have been recorded close to the volcano (Lavecchia et al., 2007). Another set of seismic events (hypocenter depths $<10 \mathrm{~km}$ ) was observed underneath the eastern flank of Mt Etna. This small scale variation in location and kinematics of seismic events leads to the interpretation that the stress field underneath Mt Etna is highly heterogeneous (Cocina et al., 1997).

\subsection{Mt Etna's eastern flank and its slope instability}

Large volcano edifices are well known for their hazardous potential due to gradual volcano spreading (van Wyk de Vries and Francis, 1997). In comparison with other large volcano edifice instabilities, such as the Hawaiian Islands (e.g., Borgia and Treves, 1992; Moore

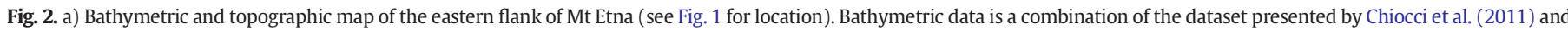

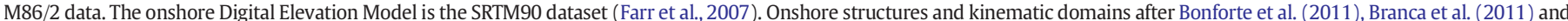

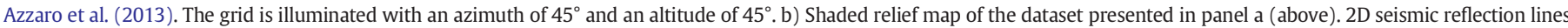

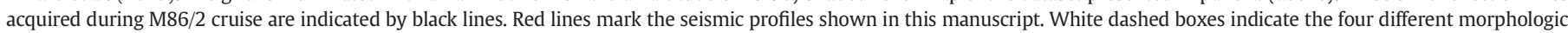
areas discussed below; i) Riposto Ridge, ii) Basins at the continental toe, iii) Amphitheater Bulge, Valle di Archirafi, Riposto Depression, and iv) Timpe Plateau \& Catania Canyon. 


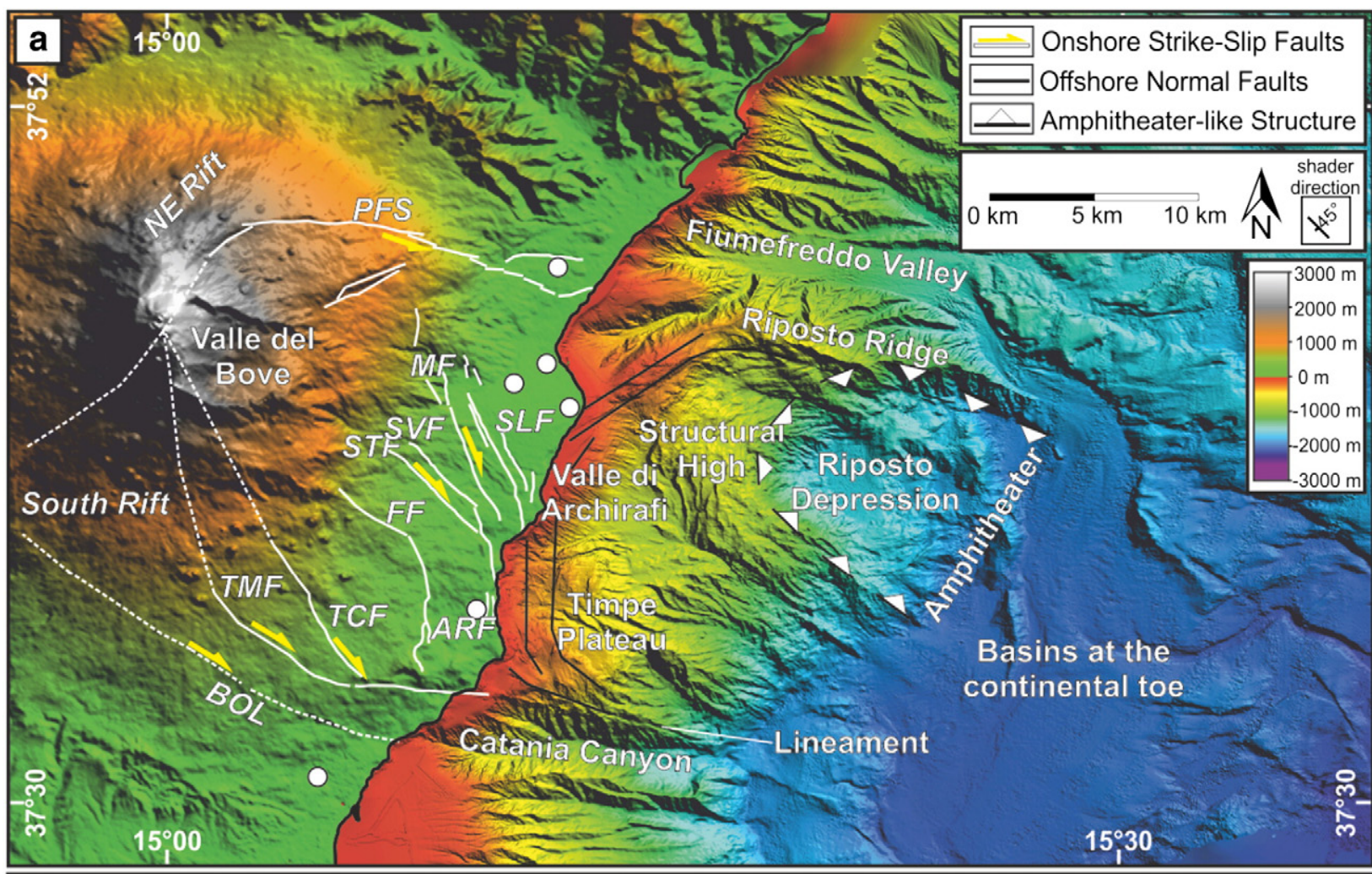

Northern Fault System: PFS=Pernicana Fault System

Timpe Fault System: $\boldsymbol{M F}=$ Moscarello; $\boldsymbol{S V F}=S$. Venerina $S T F=S$. Tecla; $\boldsymbol{S L F = S . L e o n a r d e l l o ; ~} \boldsymbol{F F = F i a n d a c a ; ~} \boldsymbol{A R F = A c i r e a l e}$

Southern Fault System: $T M F=T r e m e s t i e r i ; ~ T C F=T r e c a s t a g n i ; ~ B O L=B e l p a s s o-O g n i n a ~ L i n e a m e n t$

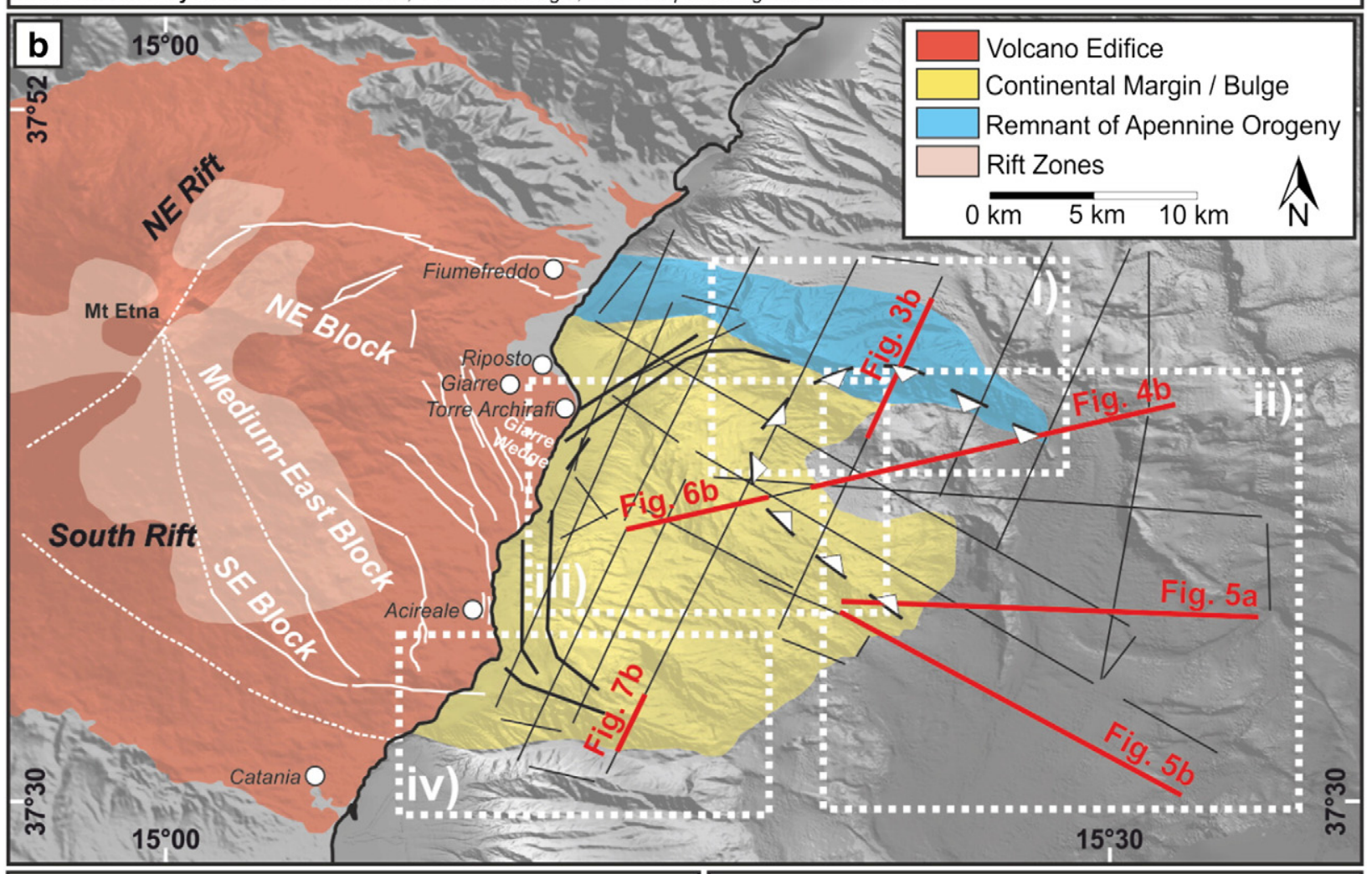

i) Riposto Ridge (Fig. 3)

ii) Basins at the continental toe (Figs. 4,5)

iii) Amphitheater Bulge, Valle di Archirafi, Riposto Depression (Fig. 6)

iv) Timpe Plateau \& Catania Canyon (Fig. 7) 
et al., 1989; Nakamura, 1980) and the Canary Islands (Krastel et al., 2001; Masson et al., 2002), the setting at Mt Etna differs dramatically, as the volcano edifice builds upon continental crust, creating a volcano flank instability at the edge of the continental margin. The volcano flank gravitational instability (e.g., Firth et al., 1996) is considered to creep on a weak substratum-décollement like a pre-Etnean landslide deposit (Nicolosi et al., 2014) or a dipping weak clay-rich layer or substratum (e.g., Delcamp et al., 2008).

Mt Etna's flank instability, first described as gravitational spreading by Borgia et al. (1992), is one of the best-monitored and studied examples for volcano flank instability around the world. Evidence for both, episodic and continuous flank movement, was reported (e.g., Acocella et al., 2003; Bonforte and Puglisi, 2003; Froger et al., 2001). It was possible to locate and characterize the instability of Mt Etna's eastern flank by a dense network of GPS and geodetic stations (Bonforte et al., 2009; Lundgren et al., 2003; Neri et al., 2009; Puglisi et al., 2008), gas monitoring (Bonforte et al., 2013; Neri et al., 2007), and geologic fieldwork (Groppelli and Tibaldi, 1999; Neri et al., 2004).

The northern boundary of the moving flank is interpreted to coincide with the left-lateral Pernicana-Provenzana Fault System (PFS) (Fig. 2). The PFS shows a continuous horizontal displacement of $\sim 2.8 \mathrm{~cm} /$ a over the last decades (Groppelli and Tibaldi, 1999) that may even accelerate during volcanic activity (Bonforte et al., 2007). The sharp morphologic expression of the PFS vanishes closest to the Ionian coast and can only be traced by small NNE-SSW trending scarps in the shallow offshore realm (Argnani et al., 2012; Chiocci et al., 2011). The central sector of the instable volcano flank is dominated by the Timpe Fault System (Figs. 1, 2) separating the NE-Block to the Medium East Block (Fig. 2) (Azzaro et al., 2013; Bonforte et al., 2011). This fault system is defined by several normal faults that also show some rightlateral slip components (Azzaro et al., 2013; Bonforte et al., 2011) (Fig. 2). The NNW-SSE trending Moscarello fault (MF) (Fig. 2) shows the most prominent scarp of the Timpe Fault System (Azzaro et al., 2013). The southern boundary of the instable flank is described by the Tremestieri Fault (TMF), the Trecastagni Fault (TCF) and the inferred Belpasso-Ognina lineament (BOL) (Fig. 2). The TMF forms a semicircular shape and shifts from a NNW-SSE trending fault at the crest of Mt Etna to a W-E trending fault close to the coast. The TCF is a branch of this fault with a NW-SE trend. Whereas TMF and TCF have surface expressions in the coastal areas, BOL is only constrained by InSAR and soil gas emissions (Bonforte et al., 2013; Froger et al., 2001). The TMF and TCF are also inferred towards the crestal craters of Mt Etna (Fig. 2) (Azzaro et al., 2013).

In contrast to the well-studied onshore part, little information is available concerning the morphology and structure of the offshore flank of Mt Etna, and the transition towards the continental margin. Marani et al. (2004) presented the first multi-beam bathymetric map of the area, imaging the major morphological features offshore Mt Etna. Chiocci et al. (2011) acquired and used a high-resolution bathymetry for a first interpretation on the continental margin offshore Mt Etna.

Chiocci et al. (2011) proposed the idea of an upslope propagating instability, caused by a large-scale mass wasting event offshore Mt Etna, creating a prominent amphitheater-like structure off the village of Riposto (Fig. 2). Furthermore, the multi-beam bathymetric map shows an ESE trending lineament at the seafloor at a location which may coincide with an offshore continuation of the suggested terrestrial boundary of the Southern Fault System (Chiocci et al., 2011). Reflection seismic data indicate that the offshore area around the volcano is dominated by extensional faulting, with only a few isolated thrust faults close to the coast at Riposto Ridge (Argnani et al., 2013). So far, it was not possible to determine the exact northern and southern boundaries of the moving flank in the marine realm (Argnani et al., 2013). The instability of Mt Etna's continental margin is documented by large scale submarine mass wasting deposits (Pareschi et al., 2006) and small/medium scale debris deposits (Gross et al., 2014).

\subsection{Objectives}

We collected a high-resolution acoustic dataset including multi-beam bathymetry, sediment echo sounder and 2D seismic reflection lines in order to investigate the tectonic setting of the continental margin offshore Mt Etna and its linkage to onshore volcanic and tectonic processes. The main objective of this manuscript is to link tectonic features and processes between the on- and offshore areas around the volcano with special emphasis on evaluating the impact of offshore processes, such as the continental margin instability, on Mt Etna's flank instability. On a long-term perspective, the results may contribute an improved hazard assessment for the entire on- and offshore system consisting of the onshore eastern volcanic flank and the submarine continental margin off Mt Etna.

\section{Methods}

During RV Meteor Cruise M86/2 from December 2011-January 2012, a new seismic and hydro-acoustic dataset was acquired offshore Mt Etna. Recording of 2D seismic signals was realized by using a 104-channel Geometrics GeoEel digital streamer with a group interval of $1.56 \mathrm{~m}$.

A 1.7 l GI Gun was operated at 200 bar in harmonic mode with a shot interval of $4 \mathrm{~s}$, resulting in an average shot-spacing of $\sim 8 \mathrm{~m}$, and achieved a general sub-bottom penetration of up to $1 \mathrm{~s}$ TWT. A dense grid of 2D reflection seismic profiles offshore Mt Etna was collected with this system (Fig. 2a).

The seismic profiles were processed using the commercial software package Gedco Vista Seismic Processing. Processing including a 20/40/ 200/400 Hz band pass filter, despiking, CMP-binning, Normal-MoveOut Correction and debias-filtering. The CMP bin size was set to $2 \mathrm{~m}$, which resulted in an average fold of 14 . Due to the limited offset range of the relatively short streamer, Normal-Move-Out is not sensitive to a dedicated velocity analysis. Therefore, a constant velocity of $1500 \mathrm{~m} / \mathrm{s}$, which resulted from an iterative process, was applied to the dataset. All data were time-migrated by using the software's finite difference migration method with a constant velocity of $1500 \mathrm{~m} / \mathrm{s}$.

Bathymetric data were acquired with a hull-mounted Kongsberg EM122 mutlibeam-echosounder. The presented bathymetric grid in this work has a cell size of $30 \times 30 \mathrm{~m}$ and represents a combination of the bathymetric data presented by Chiocci et al. (2011), and the new acquired M86/2 dataset. Parametric echo-sounder data were acquired by using RV Meteor's hull mounted Teledyne Atlas Hydrographic Parasound P70.

\section{Results}

To account for the complex morphology offshore Mt Etna, we divided the study area off Mt Etna's eastern flank into four different morphological areas (boxes in Fig. 2):

\section{i) Riposto Ridge}

ii) Basins at the toe of the continental margin

iii) The Amphitheater, the adjacent Valle Di Archirafi and the Riposto Depression

iv) Timpe Plateau and the southern boundary of the moving flank.

These individual areas will be described separately before being combined in a general discussion of the regional tectonics.

\subsection{Riposto Ridge}

Riposto Ridge (RR) is a prominent W-E trending, $\sim 22 \mathrm{~km}$ long and up to $\sim 6 \mathrm{~km}$ wide ridge, that rises up to $700 \mathrm{~m}$ above the surrounding seafloor (Fig. 3). Its eastern extends are bent towards the south. Its southern flank reveals slope gradients of up to $30^{\circ}$, whereas the northern flank is characterized by slope gradients of $\sim 10-20^{\circ}$. The ridge is shaped by multiple gullies and channels with an increase in channel 


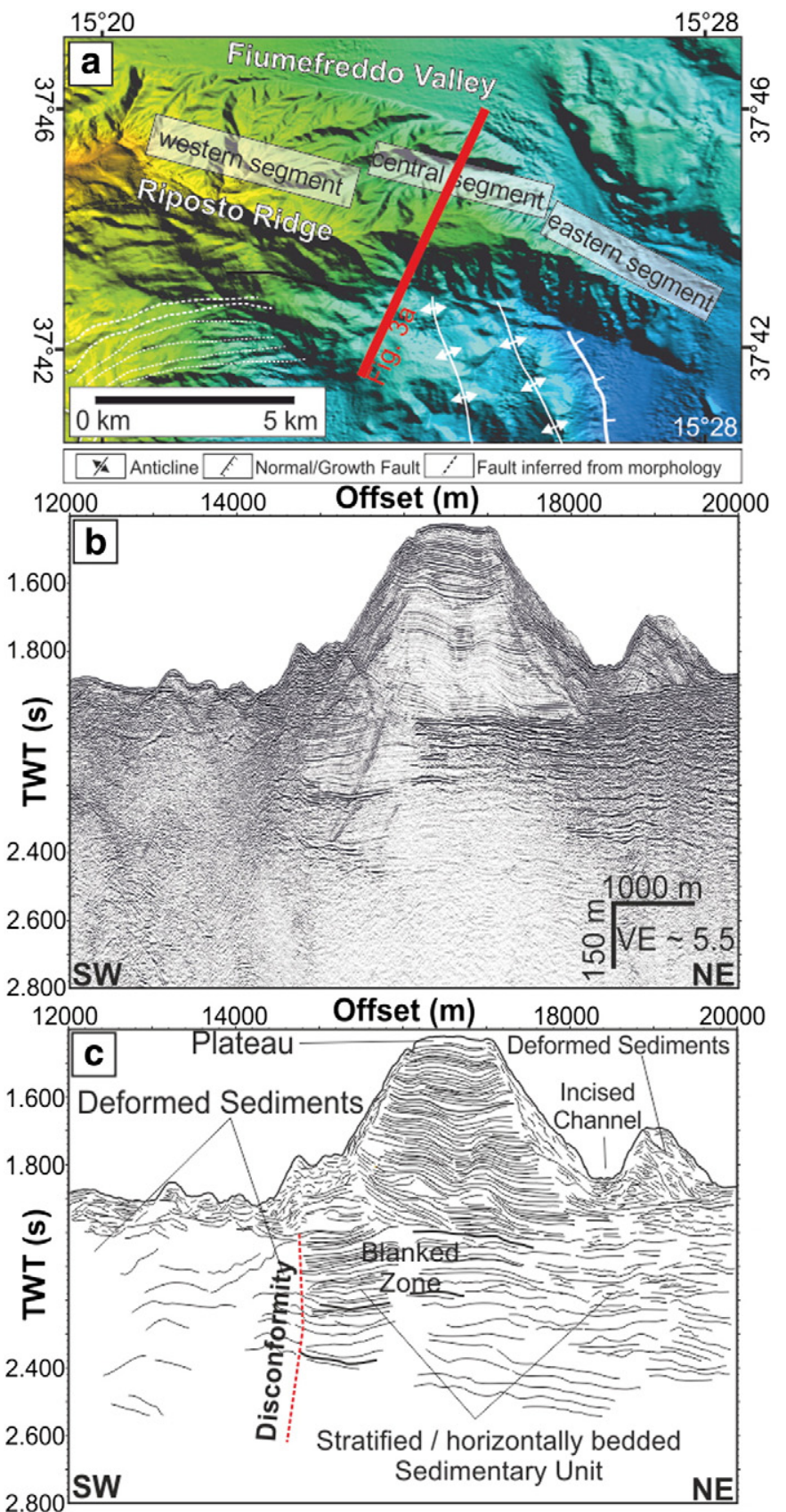

Fig. 3. a) Morphology of Riposto Ridge (RR) and its surroundings. RR is a prominent elongated ridge at the northern boundary of Mt Etna's moving flank. The northern realm of RR is characterized by two E-W trending incised channels, which are overprinted by gullies and secondary channels. See Fig. 2 for location of map. b) SW-NE trending seismic profile M86-2-248 crossing the central segment of RR (see panel a for location). c) Line drawing of the seismic profile. The ridge reveals a low grade of internal deformed in its upper units and is underlain by undisturbed well-stratified sedimentary units, which strike out at a disconformity towards the south. South of this disconformity, the onset of the deformed continental margin facies off Mt Etna can be observed. The surface of the central segment of RR appears as a flat plateau-like feature. The origin and tectonic control of RR are still debatable.

density at the northern flank where they cut up to $\sim 150 \mathrm{~m}$ into the subsurface (Fig. 3). For simplification of the morphological and internal structures of RR we divide the ridge into three segments; the western-, the central- and the eastern segments.

The western segment is characterized by a morphological connection to the amphitheater structure (see below) and reveals semicircular scarps at its southern flank that can be traced into the crest of the amphitheater structure (Fig. 2). In the central segment (Fig. 3), deeply incised channels are imaged at the northern side of the ridge. Here, sediments with a low grade of internal deformation can be observed in the upper $\sim 300 \mathrm{~m}(\sim 0.4 \mathrm{~s}$ TWT) of sediments, which are underlain by a package of high amplitude continuous reflections; these high amplitude, continuous reflectors can be traced towards the northern end of the seismic line shown in Fig. 3b. This seismic unit is discontinued underneath the southern flank of the ridge and the morphology shows a plateau at this part of the ridge (Fig. 3). Furthermore, this unit cannot be traced within the continental margin directly in front of Mt Etna and therefore displays a prominent disconformity in this region. It is not resolved if this disconformity is fault-bound. The eastern segment of the ridge includes the tip of the ridge, which shows a decrease in the ridge's width and is bent towards the south (Fig. 3).

\subsection{Basins at the toe of the continental margin}

Three sedimentary basins, the West, Central and East Basins (Fig. 4), are observed offshore Mt Etna at the toe of the continental margin. All basins widen towards the south (Figs. 2, 4). They are separated from each other by two buried anticlines (A and B in Figs. 4 and 5). This basin system is bounded to the east by the limb of a rollover-anticline (Figs. 4, 5). Anticlines A and B have a clear surface expression in the northern and central part of the working area, but plunge beneath the sedimentary basin fill towards the south, where no seafloor expression is visible. The general attitude of the hinge lines of the anticlines is convex with respect to the continental toe (Fig. 4). The anticlines have a thin sedimentary cover which does not exceed $\sim 100 \mathrm{~ms}$ TWT $(\sim 75 \mathrm{~m})$ (Figs. 4, 5). The anticlines host a seismic facies of low amplitudes, but continuous reflectors defining an upright fold with an axial plane steeply dipping to the west (Fig. 5). The rollover-anticline towards the east has no distinct surface expression, except for an uplift of strata around the axis of the fold (Figs. 4, 5).

The large East Basin shows maximum widths of $\sim 12 \mathrm{~km}$ and sediment thicknesses of up to $750 \mathrm{~m}$ (1000 ms TWT) (Fig. 4). The seafloor is inclined towards the south (Fig. 4). The northernmost tip of East Basin lies south of RR. East Basin can generally be described as an asymmetric half-graben, limited by a westward dipping growth fault in the west and the limb of a buried anticline in the east (Fig. 4a). This basin can be traced towards the south where it does not show indications for an anticline west of its growth fault (Argnani and Bonazzi, 2005; Bianca et al., 1999; Nicolich et al., 2000). Based on a seismic facies characterization, the sediment infill of East Basin subdivides into four major seismic units (Figs. 4, 5):

- Unit-A: The lowermost seismic unit (Figs. 4, 5) is characterized by low amplitude, continuous reflectors that dip to the west. Strata have uniform thicknesses and show little internal deformation. The seismic facies of Unit A is similar to the shallow sub-surface sediments to the east of the East Basin, indicating the spatial continuity of Unit A into this area (Figs. 4, 5). Nevertheless, it is not possible to trace any horizons from Unit A into the area east of East Basin.

- Unit-B: The boundary zone between Unit A and Unit C is characterized by a seismic unit, which is only visible in the southernmost profiles and thickens towards the south (Fig. 5). Acoustically, Unit $\mathrm{B}$ is characterized by moderate amplitude, chaotic reflectors.

- Unit-C: The central Unit C is characterized by high-amplitude continuous reflectors, pinching out towards the east (Figs. 4, 5). In the eastern part of East Basin, uplift of strata is visible, whereas the western boundary of the basin is marked by a growth fault and subsidence.

- Unit-D: The uppermost Unit D (Figs. 4, 5) is characterized by subhorizontal reflectors with almost no internal deformation. Towards anticline B (Figs. 4, 5), the uppermost strata form a moat, whereas towards the east they form part of the rollover-anticline described above (Fig. 5). 


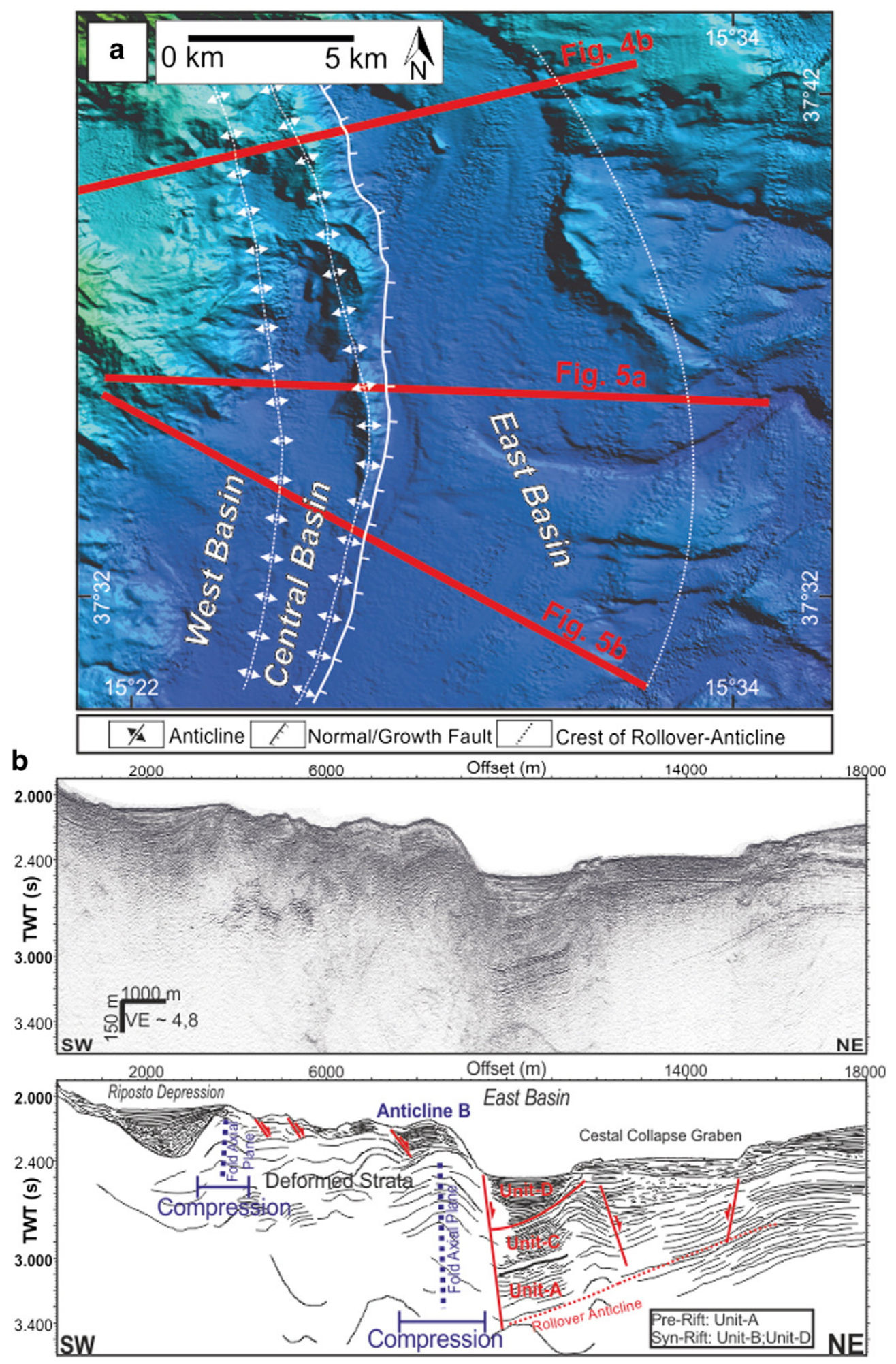

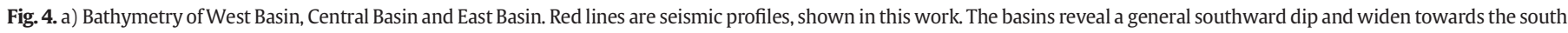

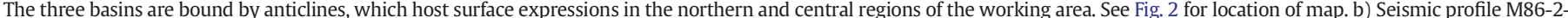

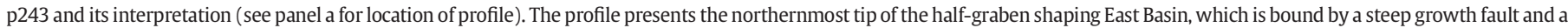

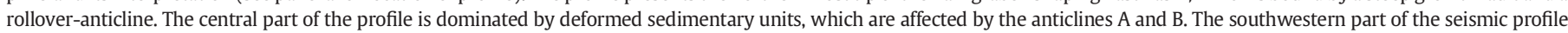
images Riposto Depression, which is a sedimentary basin at the toe of the steep Amphitheater headwall (see below).

Central Basin (Figs. 2, 4a) shows a maximum width of $\sim 3000 \mathrm{~m}$ and reveals a sediment infill of $\sim 150 \mathrm{~m}$ (200 ms TWT). It is separated from the East Basin (Fig. 4) by anticline B and towards the West by anticline A. It reveals well-stratified, high amplitude, continuous reflectors, which terminate at the flank of anticline A and anticline B (Fig. 5).
Farther towards the toe of the continental margin, West Basin lies adjacent to Mt Etna's eastern flank (Figs. 2, 4a). It is only present in the southernmost profiles across the sedimentary basins; seafloor morphology suggests that it continues farther to the south (Figs. 4a, 5b). Its boundary is defined by anticline A (Figs. 4a, 5b), separating it from the 

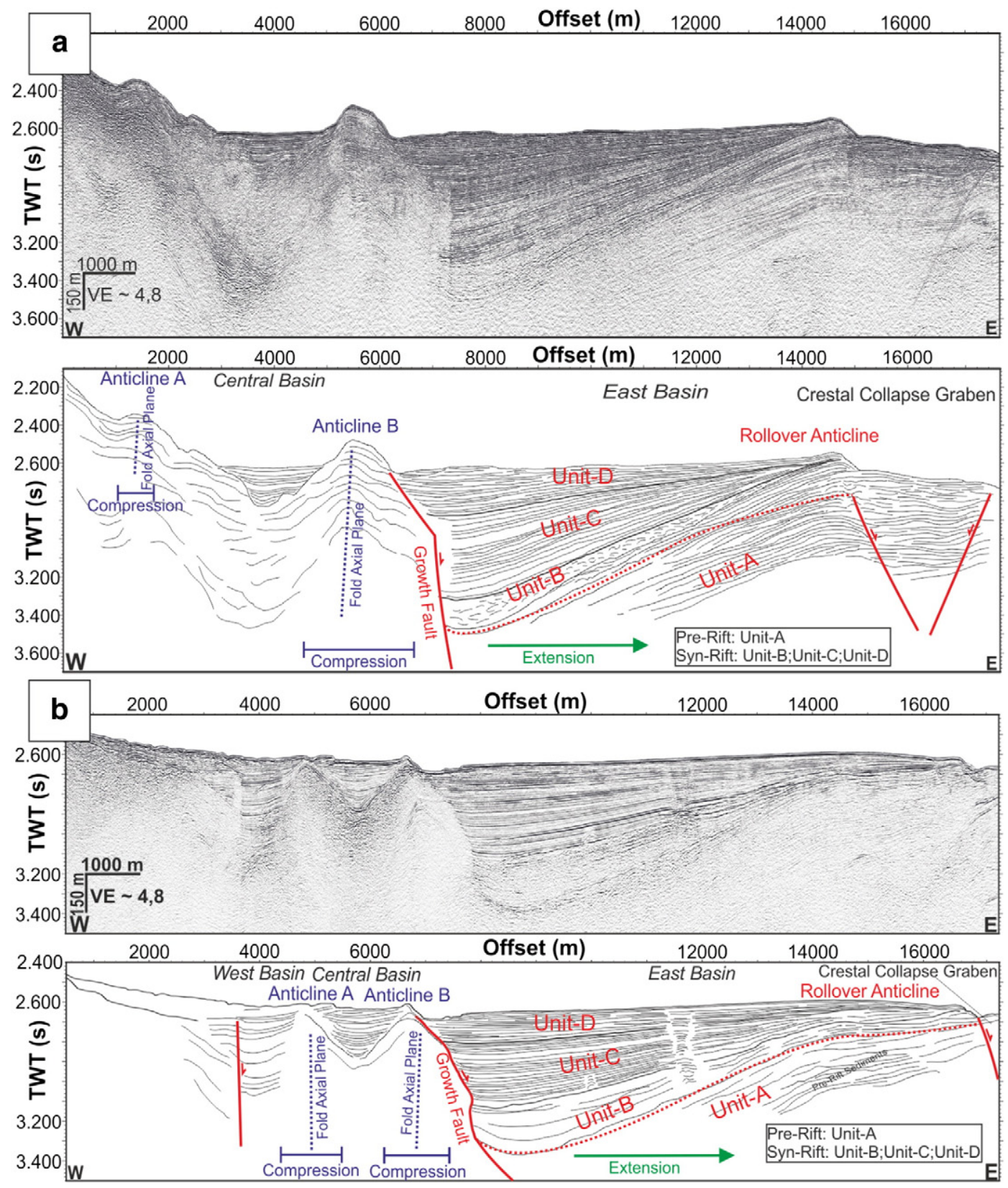

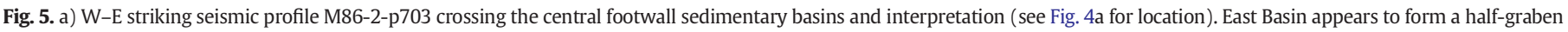

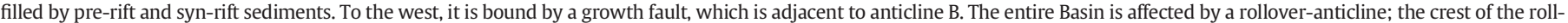

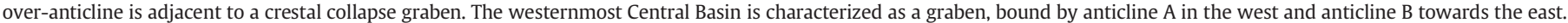

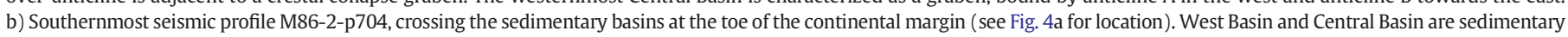

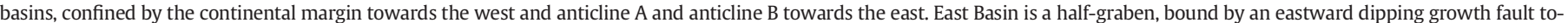
wards the west; it is underlain by the rollover-anticline; the crest of this rollover-anticline is outcropping in the east. The onset of a crestal collapse graben is visible in the east.

Central Basin (Fig. 4). It reveals widths of up to $4000 \mathrm{~m}$, whereas its sedimentary infill extends up to $490 \mathrm{~m}(\sim 650 \mathrm{~ms}$ TWT) (Fig. 5). Its internal structure is dominated by westward dipping high amplitude reflectors, terminating in the East against anticline $\mathrm{B}$ (Fig. 5). To the west, West Basin is constrained by the continental margin and an adjacent shallow dipping fault (Fig. 5).

\subsection{The amphitheater and the Valle Di Archirafi}

South of RR, the massive amphitheater-like structure with an estimated headwall length of $\sim 20 \mathrm{~km}$ represents one of the most prominent seafloor features offshore Mt Etna (Chiocci et al., 2011; Gross et al., 2014) (Fig. 6a). The amphitheater encloses the Riposto Depression, a small basin with a lateral extent of $\sim 13.5 \mathrm{~km}^{2}$ (Fig. 6a). Seismic reflection data and parametric sediment echo-sounder data across Riposto Depression reveal an internal seismic facies, dominated by high amplitude reflectors intersected by localized chaotic seismic units that are interpreted as mass transport deposits (Gross et al., 2014) (Fig. 4).

The amphitheater headwall is located at the eastern section of a structural high (Fig. 6a). Prominent northward trending ridges with lengths between 2500 and $5500 \mathrm{~m}$, and heights of up to $60 \mathrm{~m}$ are present on the western part of the seismic profile shown in Fig. 6 a. The morphological expression of these ridges vanishes towards the southern flank of Riposto Ridge.

The Valle Di Archirafi (VdA) is located west of the amphitheater's headwall and the prominent structural high (Fig. 6a). This funnel-shaped sedimentary system covers an area of $\sim 55 \mathrm{~km}^{2}$ and is 

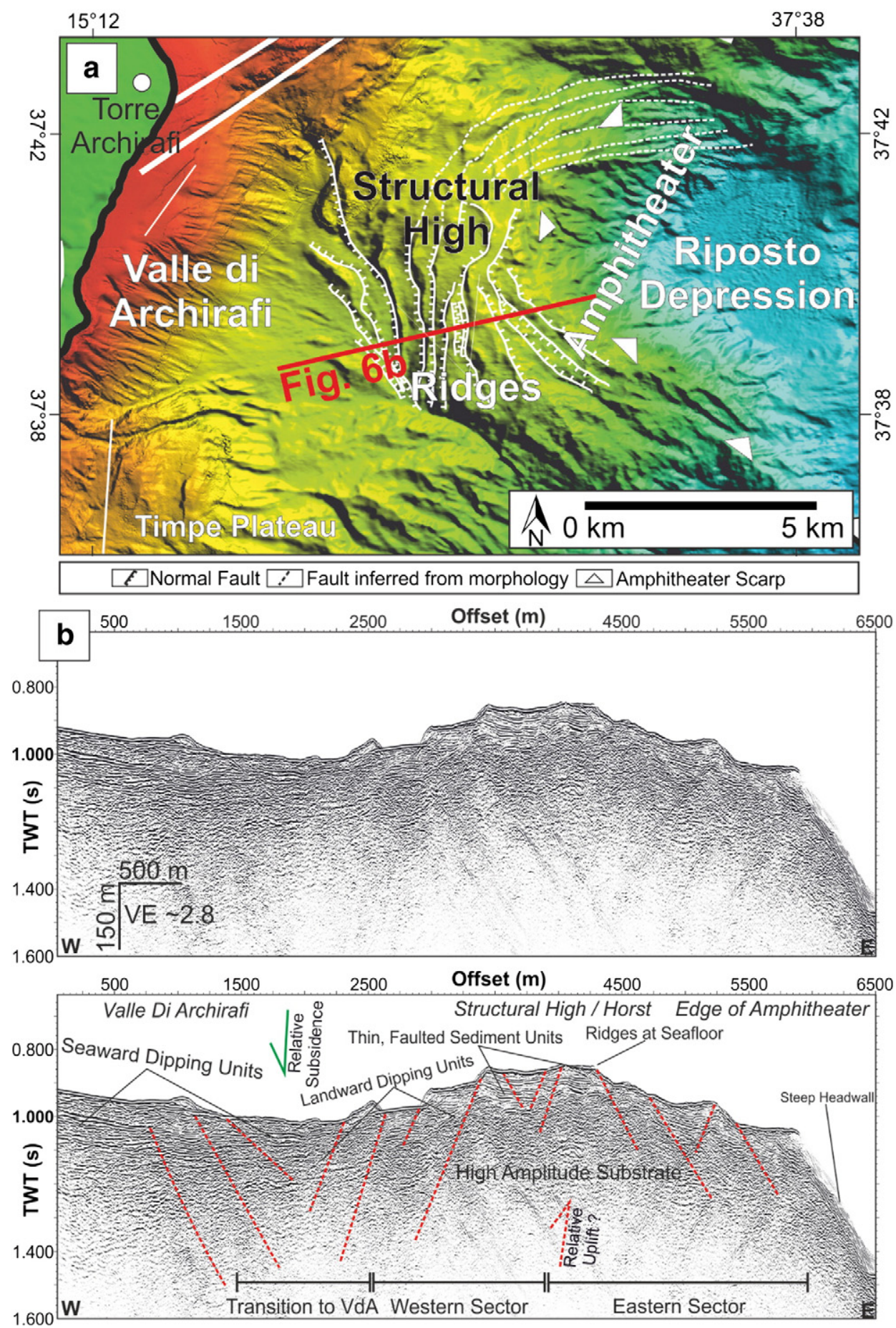

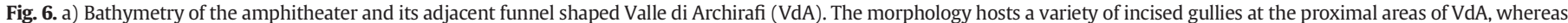

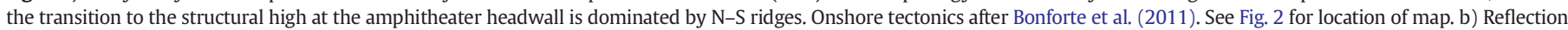

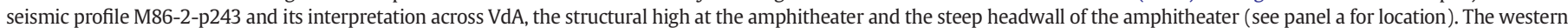

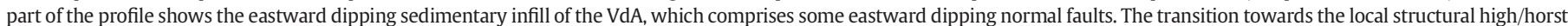

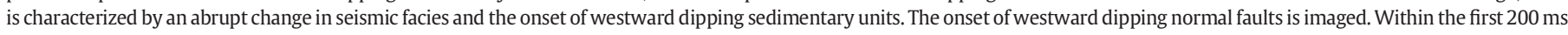

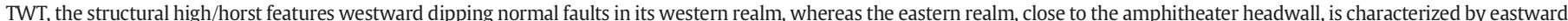

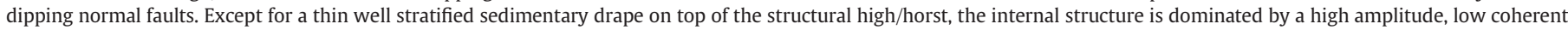
substrate.

characterized by multiple small WNW-striking gullies and channels cutting into the deposits close to the coastline (Fig. 6).

The internal sedimentary architecture of VdA exhibits seaward dipping units, that abut against the structural high (Fig. 6b, c). They are characterized by well-stratified continuous seismic reflector packages interlayered with chaotic to transparent units. Some reflectors in the lower parts of VdA indicate diverging reflection pattern towards the west. Towards the structural high, east-dipping normal faults appear to produce small displacements in the lower part of the strata. Sediments of VdA are separated from the structural high to the east by a set of westward dipping normal faults and a change in seismic facies. The structural high is characterized as a horst close to the edge of the 
amphitheater headwall (Fig. 6). The internal seismic facies is dominated by high-amplitude units, which reveal a low coherency. The structural high is draped by a thin sedimentary cover with a thickness of $\sim 150 \mathrm{~ms}$ TWT and can be separated into two major sectors (Fig. 6b). The western sector is characterized by west-dipping normal faults, whereas the eastern sector is characterized by east-dipping normal faults. The surface expression of all faults observed in the seismic lines correlates with topographic lows in the pattern of the north-south trending ridges described above (Fig. 6a).

\subsection{Timpe Plateau and Catania Canyon}

The Timpe Plateau (TP) comprises the southern sector of Mt Etna's offshore bulge (Fig. 7). Its morphological expression is dominated by east-southeast trending channel- and gully systems cutting up to $60 \mathrm{~m}$ into the underlying strata (Fig. 7a). The southern boundary of TP is marked by the incision of the Catania Canyon (CC) (Fig. 7a). The topographic ridge immediately north of CC hosts a lineament at its crest with a $292^{\circ}$ strike direction (Fig. 7a). This lineament can be traced over a distance of $\sim 9.5 \mathrm{~km}$ down to the depositional basin at the toe of the continental slope. It forms a morphological depression about $20 \mathrm{~m}$ deep. The depression is about $\sim 850 \mathrm{~m}$ wide close to the coastal zone and narrows down to $\sim 200 \mathrm{~m}$ at the eastern, seaward end.

High-resolution reflection seismic data show a set of faults just south of the topographic depression, and on the northern flanks of Catania Canyon (Fig. 7b). Fault attitudes and offsets point towards a positive flower structure with only a few meters of vertical displacement of the strata in the seismic section (Fig. 7c). Positive flower structures owe their geometry to transpressive movements across a strike-slip fault. Due to high slope gradients and indications for a strong overprint by submarine mass movement events and bottom current activity (Gross et al., 2014), the geomorphic expression of the fault system is restricted.

\section{Discussion}

\subsection{The architecture of the continental margin}

The tectonic systems, confining the onshore volcano flank movements, are well documented (e.g., Azzaro et al., 2013; Bonforte et al., 2011 ) (Fig. 8). Hence, we will here concentrate on the offshore realm, mostly expressed by the continental margin off East Sicily. The largescale morphology of the margin is characterized by an east oriented convex bulge that hosts high slope gradients of up to $25^{\circ}$, as well as multiple deeply incised gullies and channels between the cities of Catania and Fiumefreddo (Chiocci et al., 2011) (Figs. 2, 8). This bulge may display a response of a non-axial magmatic inflation (Azzaro et al., 2013; Chiocci et al., 2011) related to a high velocity body (HVB) (Chiarabba et al., 2004) or a response to pre-etnean thrust faulting at the continental margin (Argnani et al., 2013). The margin can be subdivided into different areas, which are defined by their morphological expression and/ or their tectonic origin; these areas are discussed in the following.

\subsubsection{Riposto Ridge}

Riposto Ridge is located at the expected seaward extension of the left-lateral Pernicana-Provenzana Fault System (PFS). PFS is supposed to display the northern boundary of Mt Etna's moving flank (Bonforte and Puglisi, 2003, 2006; Bonforte et al., 2007) (Fig. 8). Riposto Ridge was postulated to be a submarine extension of the thrust of the Appennine Chain, which was confined by dredging of hard rocks at the northern flank of Riposto Ridge (Bousquet et al., 1998; Gabbianelli et al., 1995). In contrast to the brittle deforming PFS onshore, Riposto Ridge is affected by a diffuse grade of internal deformation (Argnani et al., 2013) (Fig. 3). The northern flank of RR is underlain by a uniform, thick, and well-bedded seismic unit (Fig. 3). This unit is not present south of RR at the northern onset of the continental margin in front of
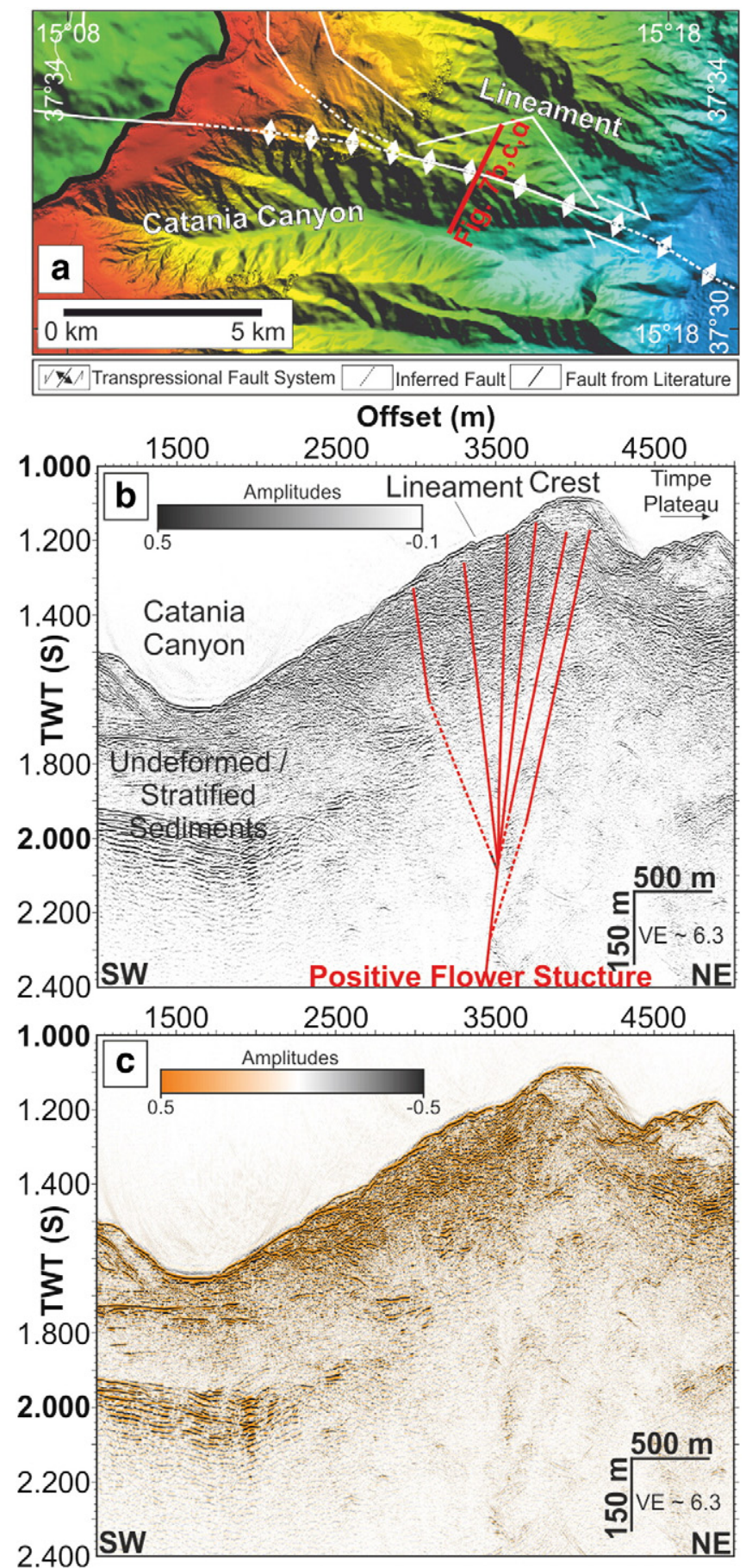

Fig. 7. a) Bathymetry at the proposed southern boundary of Mt Etna's moving flank. According to Chiocci et al. (2011), the $292^{\circ}$ striking lineament north of Catania Canyon represents the seafloor expression of the southern boundary of the moving flank. See Fig. 2 for location of map. b) Seismic profile M86-2-p246 across Catania Canyon and the lineament illustrated with white-black color bar (see panel a for location). The subsurface structure at the lineament shows a positive flower structure with faults outcropping at the seafloor. c) Seismic profile M86-2-p246 is illustrated with orange-white-black color bar.

Mt Etna (Fig. 3). This indicates that RR is located at a major geological discontinuity between the continental margin north of this prominent E-W trending ridge and the deformed continental margin offshore Mt Etna. This lends support to the interpretation that RR represents the northern boundary of Mt Etna's instable continental margin. Nevertheless, it is still unclear and to evaluate, if RR is controlled by a major structural fault or discontinuity in this area. 


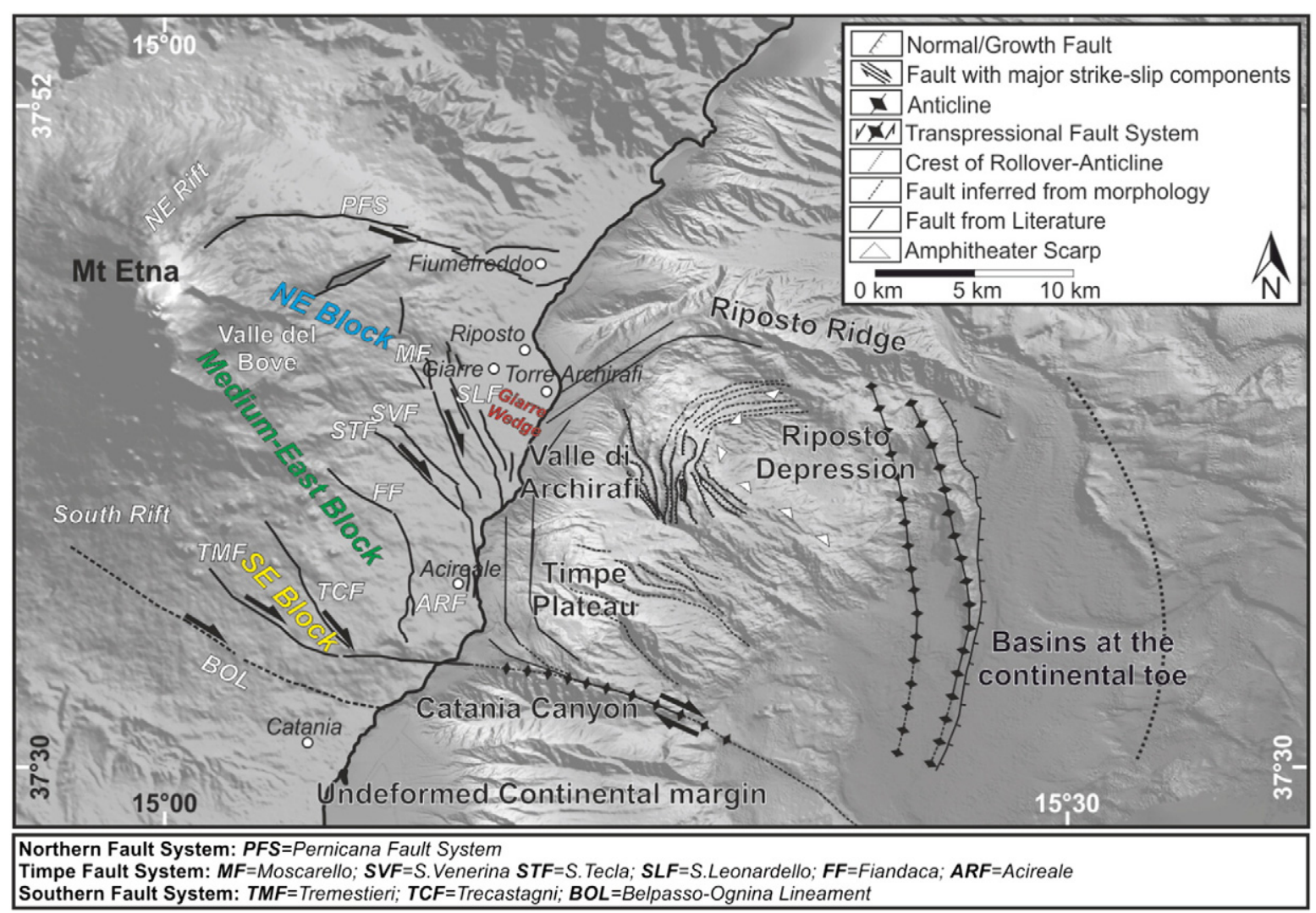

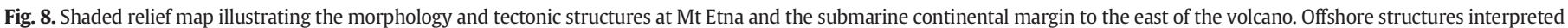
from the new seismic reflection dataset presented in this study combined with interpretations of onshore features from Bonforte et al. (2011) and Azzaro et al. (2013).

\subsubsection{Timpe Plateau and Catania Canyon}

Argnani et al. (2013) interpreted the Timpe Plateau (Figs. 8) as the seaward extension of the Hyblean foreland as only a small grade of internal deformation is visible in their seismic data. The bathymetric data presented by Chiocci et al. (2011) together with the new data presented in this study, show that the entire plateau, alike the entire continental margin east of the volcano edifice, is heavily overprinted by denudation. This manifests in a variety of erosional features like channels and gullies, which are the dominating morphological structures in the entire area (Figs. 7, 8). Next to erosional structures, also the input of volcanic material plays an important role, as the Timpe Plateau was overprinted by volcanic products from the fissure type Timpe volcanism 250-100 kyr BP (Branca et al., 2004). The presence of surface near volcanic- and volcanic-clastic material at the Timple Plateau would explain the low penetration of the seismic signals in this region. The Timpe Plateau is limited towards the south by the prominent W-E trending Catania Canyon (CC) (Fig. 8). North of CC, a prominent ESE lineament can be observed at the crest of the ridge, limiting CC towards the north. Chiocci et al. (2011) considered this ESE lineament at the seafloor as the surface expression of the offshore extension of the Tremestieri Fault System, which is considered to be a part of the southern boundary of the moving flank (e.g., Azzaro et al., 2013; Bonforte et al., 2011) (Fig. 8). The seismically imaged positive flower structure underlying the ESE seafloor lineament (Fig. 7) strongly supports the interpretation of a transpressional regime underneath the ESE lineament. Considering the slip motion of the onshore fault, this fault likely represents a right-lateral transpressive fault. Similar to RR (Fig. 3), Catania Canyon is underlain by a seismic unit, which hosts horizontally bedded reflectors (Fig. 7). This seismic unit is not visible farther north at the deformed continental margin directly in front of Mt Etna. Hence, we consider that $\mathrm{CC}$ a) was not generated by tectonic processes but is the result of long lasting erosive processes and/or b) represents the onset of the continental margin that is not affected and deformed by volcanic processes related to the buildup of Mt Etna.

\subsubsection{The amphitheater and the Valle di Archirafi}

The central realm of the offshore continental margin is described by the Valle di Archirafi and its adjacent local structural high (Figs. 8). Whereas the structural high is characterized by a substrate underneath a thin sedimentary drape of up to $150 \mathrm{~m}$, Valle di Archirafi (VdA) hosts major seaward dipping units, which are confined towards the structural high (Fig. 6). Based on a seismic facies analysis, VdA likely represents an accommodation basin that catches debris from onshore sector collapses and submarine mass wasting events. The entire area is dominated by normal faulting leading to overall subsidence of the $\mathrm{VdA}$ in respect to the structural high (Fig. 6).

The semi-circular amphitheater enclosing the Riposto Depression represents the most prominent morphological feature offshore Mt Etna (Fig. 8). Its crest is characterized by extensional faults dipping towards the steep headwall (Fig. 6). Similar amphitheater-like structures are often interpreted to result from large scale mass transport events and Chiocci et al. (2011) proposed that the amphitheater off Mt Etna also originated from such an event about $0.1 \mathrm{kyr}$ ago. However, in this case, a thick mass transport deposit is expected in the shallow subsurface at the Riposto Depression and the adjacent basins at the continental toe (Figs. 4, 5). Gross et al. (2014) reported evidence for small-scale mass transport deposits in these areas but no large scale deposits were found within the upper $\sim 100 \mathrm{~m}$. Nevertheless, active faults that dip towards the steep headwall of the amphitheater offset the seafloor at the structural high adjacent to the amphitheater. Based on these observations, we consider two possible genetic origins for the amphitheater:

a) The amphitheater represents an ancient scar of a slope failure. The main deposits of this event that were evacuated into the Ionian basin are now eroded and disintegrated to a degree that seismic systems are not sensitive to resolve. Extensional tectonics and a retrogressively developing semi-circular fault system at the head of the scarp favor small scale mass wasting along the steep slopes. These 
mass transport deposits are deposited into the area of Riposto Depression.

b) The amphitheater results from tectonic activity. The semi-circular shape is generated by a major fault at the discontinuity between Valle di Archirafi and the structural high (Fig. 6). This extensional system leads to a stress focusing at the tip of the funnel shaped system and bends the entire region in an anti-clockwise rotation. This destabilization of the continental margin leads to the generation of new near-surface faults, forming the currently observed semi-circular fault systems in this region. The entire dynamic of Mt Etna's instable eastern flank promotes this instability and small scale mass transport deposits are evacuated frequently into the vicinity of Riposto Depression.

\subsection{Anticlines and basins at the toe of the continental margin}

The toe of the continental margin is characterized by the presence of tectonically controlled anticlines and basins (Figs. 4, 5, 8). Anticlines A and $B$ are open upright folds, which are located in concave-shape in front of the continental bulge (Figs. 8). The anticlines are only overlain by a thin sedimentary cover, attesting to young or active processes of deformation. Both appear to be deep-seated compressive structures indicating an east-west shortening of the sediments making up the continental toe off eastern Sicily. Due to limited penetration of the seismic signal, it remains open if the anticlines are rollover structures of a larger extensional detachment system. However, the detachment would have to be relatively shallow given the small wavelength of the structures, and should therefore show up in our seismic sections. There are three possible explanations why the detachment is not imaged by the seismic data:

a) The detachment is absent and the anticlines are isolated compressional features in front of the continental toe

b) The detachment horizon is deformed to a degree that is not resolvable with our seismic system.

c) The detachment horizon is characterized by a low seismic impedance contrast and/or minor changes in lithology and is therefore not displayed in the dataset.

Due to the absence of the detachment in our dataset, we consider the anticlines to display compressional structures in front of the deformed continental margin, which are not linked to a major detachment horizon. In addition, the concave shape of the anticline's fold axial plane in front of the continental margin favors a compressional regime at the toe of the continental margin. Its semi-circular westward opening arrangement stands in strong contrast to the eastward opening semi-circular structures, which can be observed on- and offshore. The spatial extends and terminations of the anticlines are rather diffuse or not displayed in our dataset. Towards the north, the anticlines can be traced as far as Riposto Ridge (Figs. 4b, 8). The southern extension of the anticlines is unclear (Fig. 8), as our dataset does not cover the area between the southern extends of the anticlines and the supposed transpressional fault system north of Catania Canyon (Fig. 8). Seismic data, published south of this area does not image these compressional structures (Argnani and Bonazzi, 2005; Bianca et al., 1999; Hirn et al., 1997; Nicolich et al., 2000), which leads us to interpret, that these anticlines terminate at, or north, of the lineament observable north of Catania Canyon. As these anticlines at the toe of the continental margin are therefore traceable south and north off Mt Etna, we consider these structures to be genetically linked to presence of the volcano.

The largest basin observable at the continental toe is the asymmetric half-graben of East Basin (Figs. 4, 5). The graben's growth fault, that shows vertical displacements of up to $750 \mathrm{~m}$, hosts an irregular fault plain with change in dip (Fig. 5). We consider this as an indicator for a change in deformation and growth of the asymmetric half graben. The half graben of East Basin is one of the graben systems, which can be traced farther south to an area east of the Malta Escarpment (Argnani and Bonazzi, 2005; Bianca et al., 1999; Hirn et al., 1997; Nicolich et al., 2000). Several authors suggest that the growth faults play an important role in the generation of hazardous earthquakes like the 1693 Catania Earthquake (Argnani et al., 2012; Bianca et al., 1999). The rollover-anticline (Figs. 5, 8), which was mapped east of East Basin, seems to belong to a larger tectonic system and can be traced towards the south. Nevertheless, the rollover-anticline images the same concave shape as the anticlines west of the half graben. Hence, we interpret East Basin to have a pre-etnean origin, but a strong tectonic overprint during the volcano buildup. This syn-tectonic deformation is also proven, as the basin has been overprinted in etnean times by the generation of the compressional anticlines, which manifests in an onset of eastward oriented stress in this region, leading to asymmetric faulting and rotation at its growth fault (Fig. 5). The West- and Central Basins (Figs. 4,5) are small basins, which act as sediment traps behind the evolving anticlines.

\subsection{Mt Etna's coupled volcano flank and continental margin instability}

As bulging of the East Sicily continental margin is limited to the area in front of Mt Etna's edifice, a link between volcano buildup processes and bulging at the continental margin is likely but the ultimate origin of the bulging is still debated (e.g., Argnani et al., 2013; Chiocci et al., 2011). Our new data show extensional faults within the upper $\sim 500 \mathrm{~m}$ of the sedimentary cover at the bulged continental margin (Figs. 8, 9). Furthermore, the entire continental margin is affected by a high grade of denudation, leading to an erosion of tectonic and nontectonic features. The dataset shows that Riposto Ridge and Catania Canyon are underlain by a thick, horizontally deposited seismic unit, which is not present directly east of Mt Etna. They therefore do not only display the northern and southern limits of the deformed continental margin; furthermore they can be considered as tectonically relatively inactive structures at the coast of East Sicily.

The northern limit of the instable flank of Mt Etna's edifice is bound to the left-lateral Pernicana-Provenzana Fault System (e.g., Azzaro et al., 2013; Bonforte and Puglisi, 2003). Nevertheless, it is not possible to trace this fault on seismic profiles as a distinct feature into the marine realm and the continental margin. Seismic data supports the suggestion of Chiocci et al. (2011), that the Tremestieri fault can be traced over the continental margin. This fault is shown in morphology as a prominent lineament north of Catania Canyon and characterized by a positive flower structure, indicating a transpressional fault system making up the southern boundary of the volcano edifice onshore and the continental margin offshore.

The anticlines at the toe of the continental margin indicate contraction, off the eastern flank of Mt Etna. We interpret these anticlines as the eastern limit of the observed continental margin instability (Figs. 8, 9), as they display a concave shape directly in front of the continental margin off Etna, building the juxtaposition to the semi-circular shaped fault zones of the volcano edifice and the continental margin.

Gravity gliding, gravitational collapse as well as spreading play important key factors for slope stability of continental margins (e.g., Morley et al., 2011; Peel, 2014). This applies also for Mt Etna's continental margin. As the observed fault systems display seaward and landward dipping faults (Fig. 6) which are not linked to a distinct detachment, we consider a gravitational collapse and spreading rather than a pure gliding to be present at the continental margin (Figs. 8, 9). The new dataset shows that large-scale tectonic structures can be followed from the volcano edifice towards the toe of the continental margin, therewith supporting the geometric and kinematic model proposed by Azzaro et al. (2013). The first order linkage between volcano edifice and continental margin tectonics leads to a coupled volcano edifice- and continental margin instability. The coastline therefore represents a geographic but not a tectonic boundary between the two systems. Whether the entire system is linked to a dipping substratedécollement (e.g., Wooller et al., 2004) or if the zone underneath the 

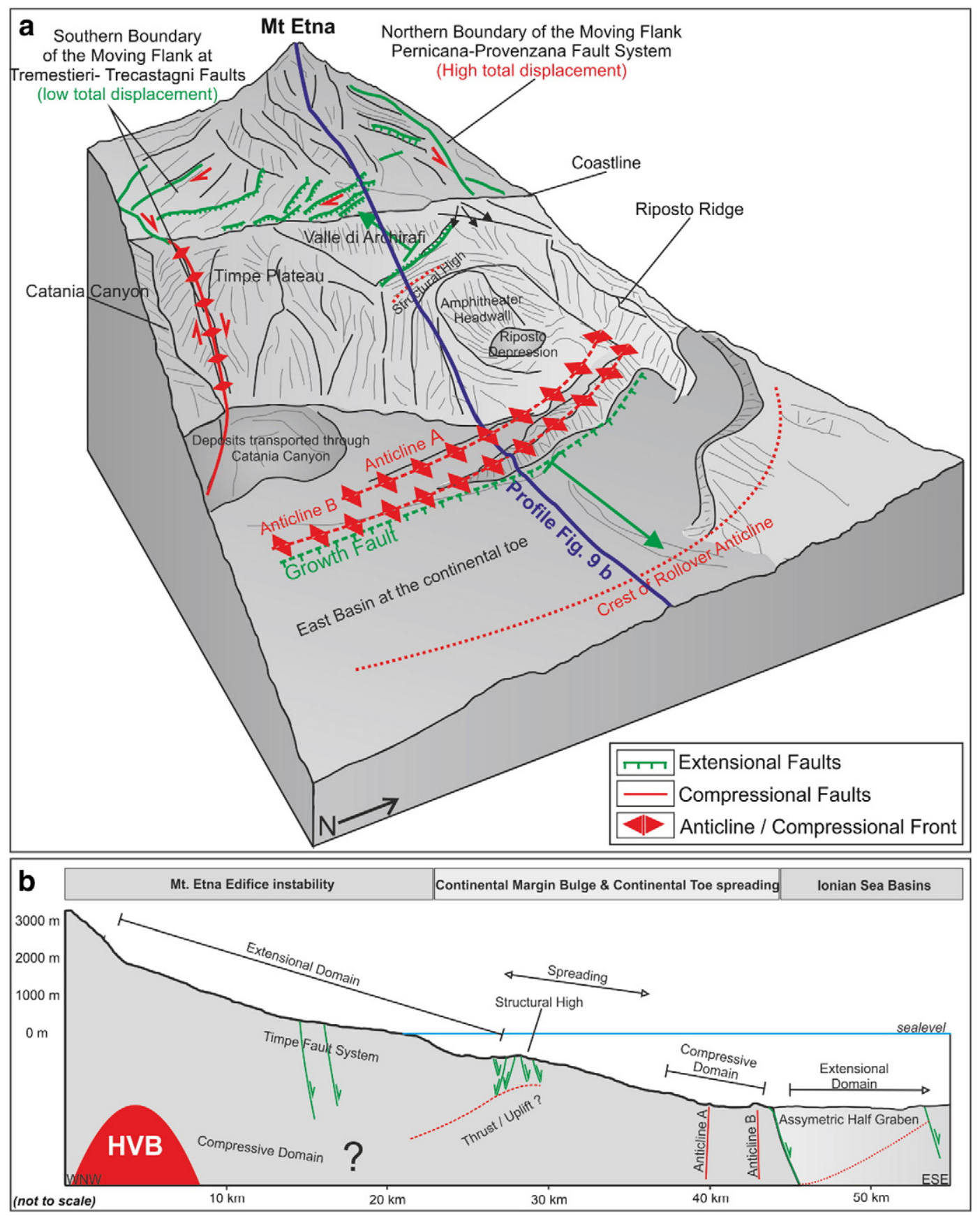

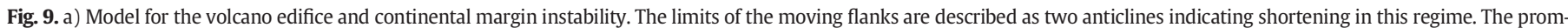

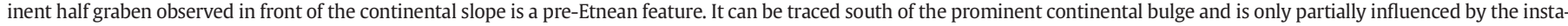

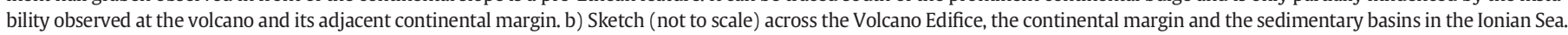

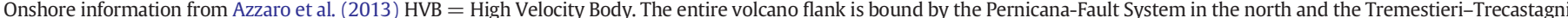

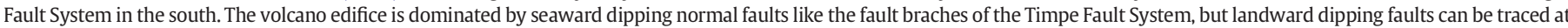

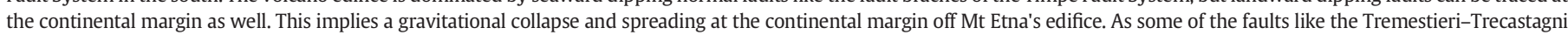

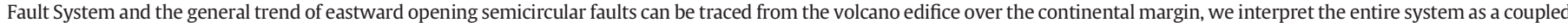
volcano edifice- and continental margin instability.

continental margin is decoupled from a detachment at depth, has still to be evaluated, as we were not able to image such a detachment.

\subsection{Deep tectonic features at the continental margin/toe offshore Mt Etna}

In contrast to deep reflection/refraction seismic data, our high resolution dataset only images the upper $1000 \mathrm{~ms}$ TWT $(\sim 750 \mathrm{~m})$ of the sedimentary succession, making it impossible to constrain deep tectonic features. Additional deep seismic data and related high-resolution seismic datasets are necessary to evaluate the trend of a possible STEP fault
(Fig. 1) (Polonia et al., 2012; Gallais et al., 2013: Argnani, 2014) in this area and to investigate if a distinct surface feature matches with this postulated crustal scale tectonic feature.

\section{Conclusions}

We analyzed new high-resolution seismic data in order to investigate near surface processes offshore Mt Etna, which are controlled by deep tectonic features as well as regional tectonic regimes. 
- In front of the toe of the continental margin, two vertical concave anticlines result from ongoing seaward migrating gravitational spreading of the continental margin. In contrast, normal faults suggest an extensional regime for the upper continental margin.

- The southern boundary of Mt Etna's moving flank is most likely located north of Catania Canyon. This area is underlain by a positive flower structure, indicating a transpressional regime. The mapped fault system is the prolongation of onshore-observed fault movements. The exact location of the northern boundary of the moving flank is still to evaluate, as Riposto Ridge shows rather low grade of deformation, then a distinct boundary fault.

- The structural high west of the amphitheater headwall is characterized by prominent ridges, which are the surface expression of a normal fault system. The structural high and the funnel shaped Valle di Archirafi show different seismic facies and are separated by a set of normal faults.

- The sedimentary basins at the toe of Mt Etna's continental margin have to be addressed to a pre-etnean genesis. The basins have been overprinted by an eastward strain in etnean times.

All findings show that the continental margin offshore Mt. Etna's edifice is strongly overprinted by recent tectonic activity. We consider a coupled volcano edifice/continental margin instability to be present, which can be traced from the toe of the continental margin towards the volcano edifice. As most of the models for Mt Etna's flank instability base on onshore observed and monitored data, we emphasize the need of advanced models, in which the continental margin spreading is addressed.

\section{Acknowledgments}

Many thanks to the crew and captain of RV Meteor for their help during the collection of data. This work is a contribution of the Cluster of Excellence "The Future Ocean" funded by the Deutsche Forschungsgemeinschaft. AM was funded by Marie Curie Career Integration Grant PCIG13-GA-2013 618149 within the 7th European Community Framework Programme. We appreciate constructive reviews of the manuscript by Dimitrios Papanikolaou and David Graindorge.

\section{References}

Acocella, V., Behncke, B., Neri, M., D'Amico, S., 2003. Link between major flank slip and 2002-2003 eruption at Mt. Etna (Italy). Geophys. Res. Lett. 30, 2286. http://dx.doi. org/10.1029/2003GL018642.

Argnani, A., 2014. Comment on the article "Propagation of a lithospheric tear fault (STEP) through the western boundary of the Calabrian accretionary wedge offshore eastern Sicily (Southern Italy)" by Gallais et al., 2013 Tectonophysics. Tectonophysics 610 195-199. http://dx.doi.org/10.1016/j.tecto.2013.06.035.

Argnani, A., Bonazzi, C., 2005. Malta Escarpment fault zone offshore eastern Sicily: Pliocene-Quaternary tectonic evolution based on new multichannel seismic data. Tectonics 24. http://dx.doi.org/10.1029/2004TC001656.

Argnani, A., Armigliato, A., Pagnoni, G., Zaniboni, F., Tinti, S., Bonazzi, C., 2012. Active tectonics along the submarine slope of south-eastern Sicily and the source of the 11 January 1693 earthquake and tsunami. Nat. Hazards Earth Syst. Sci. 12, 1311-1319. http://dx.doi.org/10.5194/nhess-12-1311-2012.

Argnani, A., Mazzarini, F., Bonazzi, C., Bisson, M., Isola, I., 2013. The deformation offshore of Mount Etna as imaged by multichannel seismic reflection profiles. J. Volcanol. Geotherm. Res. 251, 50-64. http://dx.doi.org/10.1016/j.jvolgeores.2012.04.016.

Azzaro, R., Bonforte, A., Branca, S., Guglielmino, F., 2013. Geometry and kinematics of the fault systems controlling the unstable flank of Etna volcano (Sicily). J. Volcanol. Geotherm. Res. 251, 5-15. http://dx.doi.org/10.1016/j.jvolgeores.2012.10.001.

Bianca, M., Monaco, C., Tortorici, L., Cernobori, L., 1999. Quaternary normal faulting in southeastern Sicily (Italy): a seismic source for the 1693 large earthquake. Geophys. J. Int. 139, 370-394. http://dx.doi.org/10.1046/j.1365-246x.1999.00942.x.

Bonforte, A., Puglisi, G., 2003. Magma uprising and flank dynamics on Mount Etna volcano, studied using GPS data (1994-1995). J. Geophys. Res. 108 (B3), 2153. http://dx.doi.org/10.1029/2002JB001845.

Bonforte, A., Puglisi, G., 2006. Dynamics of the eastern flank of Mt. Etna volcano (Italy) investigated by a dense GPS network. J. Volcanol. Geotherm. Res. 153 (3-4), 357-369. http://dx.doi.org/10.1016/j.jvolgeores.2005.12.005.
Bonforte, A., Branca, S., Palano, M., 2007. Geometric and kinematic variations along the active Pernicana fault: implication for the dynamics of Mount Etna NE flank (Italy). J. Volcanol. Geotherm. Res. 160 (1-2), 210-222. http://dx.doi.org/10.1016/j. jvolgeores.2006.08.009.

Bonforte, A., Gambino, S., Neri, M., 2009. Intrusion of eccentric dikes: the case of the 2001 eruption and its role in the dynamics of Mt. Etna volcano. Tectonophysics 471, 78-86. http://dx.doi.org/10.1016/j.tecto.2008.09.028.

Bonforte, A, Guglielmino, F. Coltelli, M., Ferretti, A., Puglisi, G., 2011. Structural assessment of Mount Etna volcano from Permanent Scatterers analysis. Geochem. Geophys. Geosyst. 12. http://dx.doi.org/10.1029/2010GC003213.

Bonforte, A., Federico, C., Giammanco, S., Guglielmino, F., Liuzzo, M., Neri, M., 2013. Soil gases and SAR measurements reveal hidden faults on the sliding flank of Mt. Etna (Italy). J. Volcanol. Geotherm. Res. 251, 27-40. http://dx.doi.org/10.1016/j. jvolgeores.2012.08.010.

Borgia, A., Treves, B., 1992. Volcanic plates overriding the ocean crust: structure and dynamics of Hawaiian volcanoes. Geol. Soc. Lond., Spec. Publ. 60, 277-299. http:// dx.doi.org/10.1144/GSL.SP.1992.060.01.18

Borgia, A., Ferrari, L., Pasquarè, G., 1992. Importance of gravitational spreading in the tectonic and volcanic evolution of Mount Etna. Nature 357, 231-235. http://dx.doi. org/10.1038/357231a0.

Bousquet, J.C., Gabbianelli, G., Lanzafame, G., Sartori, R., 1998. Evolution volcanotectonique de l'Etna (Sicilie): nouvelles donnèes de géologie marine et terrestre. Rapport de la Commission Internationale pour l'Exploration Scientifique de la Mer Méditerranee 35, pp. 56-57.

Branca, S., Del Carlo, P., 2004. Eruptions of Mt Etna during the past 3200 years: a revised compilation integrating the historical and stratigraphic records. In: Bonaccorso, A., Calvari, S., Coltelli, M., Del Negro, C., Falsaperla, S. (Eds.), Mount Etna Volcano LaboratoryGeophysical Monograph Series 143. American Geophysical Union, Washington, D.C., pp. 1-27.

Branca, S., Coltelli, M., Groppelli, G., 2004. Geological evolution of Etna volcano. In: Bonaccorso, A., Calvari, S., Coltelli, M., Del Negro, C., Falsaperla, S. (Eds.), Mt. Etna: Volcano LaboratoryGeophysical Monograph Series 143. American Geophysical Union, Washington, D.C., pp. 49-63.

Branca, S., Coltelli M., Groppelli G., Lentini F., 2011. Geological map of Etna volcano, 1: 50,000 scale. Italian Journal of Geosciences 130, 265-291. DOI:10.3301/ IJG.2011.15

Chiarabba, C., Gori, P., Patanè, D., 2004. The Mt. Etna plumbing system: the contribution of seismic tomography. In: Bonaccorso, A., Calvari, S., Coltelli, M., Del Negro, C., Falsaperla, S. (Eds.), Mount Etna Volcano LaboratoryGeophysical Monograph Series 143. American Geophysical Union, Washington, D.C., pp. 191-204. http://dx.doi.org/ 10.1029/143GM12.

Chiocci, F.L., Coltelli, M., Bosman, A., Cavallaro, D., 2011. Continental margin large-scale instability controlling the flank sliding of Etna volcano. Earth Planet. Sci. Lett. 305, 57-64. http://dx.doi.org/10.1016/j.epsl.2011.02.040.

Cocina, O., Neri, G., Privitera, E., Spampinato, S., 1997. Stress tensor computations in theMount Etna area (Southern Italy) and tectonic implications. J. Geodyn. 23, 109-127. http://dx.doi.org/10.1016/S0264-3707(96)00027-0.

Delcamp, A., van Wyk de Vries, B., James, M.R., 2008. The influence of edifice slope and substrata on volcano spreading. J. Volcanol. Geotherm. Res. 177, 925-943. http://dx. doi.org/10.1016/j.jvolgeores.2008.07.014

Doglioni, C., Innocenti, F., Mariotti, G., 2001. Why Mt Etna? Terra Nova 13, 25-31. http:// dx.doi.org/10.1046/j.1365-3121.2001.00301.x.

Farr, T.G., Rosen, A., Caro, E., Crippen, R., Duren, R., Hensley, S., Kobrick, S., Rodriguez, E., Roth, L., Seal, D., Shaffer, S., Shimada, J., Umland, J., Werner, M., Oskin, M., Burbank, D., Alsdorf, D., 2007. The shuttle radar topography mission. Rev. Geophys. 45. http://dx.doi.org/10.1029/2005RG000183.

Firth, C., Stewart, I., McGuire, W.J., Kershaw, S., Vita-Finzi, C., 1996. Coastal elevation changes in eastern Sicily: implications for volcano instability at Mount Etna. Geol. Soc. Lond., Spec. Publ. 110, 153-167. http://dx.doi.org/10.1144/GSL.SP.1996.110.01.12.

Froger, J.L., Merle, O., Briole, P., 2001. Active spreading and regional extension at Mount Etna imaged by SAR interferometry. Earth Planet. Sci. Lett. 187, 245-258. http://dx. doi.org/10.1016/S0012-821X(01)00290-4

Gabbianelli, G., Lanzafame, G., Lucchini, F., Pompilio, M., Rossi, L.P., Sartori, R., 1995. Indagini di geologia marina alla base orientale dell'Etna. In: Ferrucci, F., Innocenti, F. (Eds.), Progetto Etna 1993-95: Giardini, Pisa, Italy, pp. 79-84

Gallais, F., Graindorge, D., Gutscher, M.A., Klaeschen, D., 2013. Propagation of a lithospheric tear fault (STEP) through the western boundary of the Calabrian accretionary wedge offshore eastern Sicily (Southern Italy). Tectonophysics 602, 141-152. http://dx.doi.org/10.1016/j.tecto.2012.12.026.

Gallais, F., Graindorge, D., Gutscher, M.A., 2014. Reply to comment on the article "Propagation of a lithospheric tear fault (STEP) through the western boundary of the Calabrian accretionary wedge offshore eastern Sicily (Southern Italy)" by Gallais et al., 2013 Tectonophysics. Tectonophysics 610, 200-203. http://dx.doi.org/10. 1016/j.tecto.2013.10.012.

Groppelli, G., Tibaldi, A., 1999. Control of rock rheology of deformation style and sliprate along the active Pernicana fault, Mt. Etna, Italy. Tectonophysics 305, 521-537. http:// dx.doi.org/10.1016/S0040-1951(99)00035-9.

Gross, F., Krastel, S., Chiocci, F.L., Ridente, D., Bialas, J., Schwab, J., Beier, J., Cukur, D. Winkelmann, D., 2014. Evidence for submarine landslides offshore Mt. Etna, Italy. In: Krastel, S. (Ed.)Submarine Mass Movements and Their Consequences, Bd. 37, pp. 307-316. http://dx.doi.org/10.1007/978-3-319-00972-8_27

Gvirtzman, Z., Nur, A., 1999. The formation of Mount Etna as the consequence of slab rollback. Nature 401, 782-785. http://dx.doi.org/10.1038/44555.

Hirn, A., Nicolich, R., Gallart, J., Laigle, M., Cernobori, L., ETNASEIS Scientific Group, 1997. Roots of Etna volcano in faults of great earthquakes. Earth Planet. Sci. Lett. 148, 171-191. http://dx.doi.org/10.1016/S0012-821X(97)00023-X 
Krastel, S., Schmincke, H., Jacobs, C.L., Rihm, R., Le Bas, T.P., Alibés, B., 2001. Submarine landslides around the Canary Islands. J. Geophys. Res. 106. http://dx.doi.org/10. 1029/2000JB900413.

Lavecchia, G., Ferrarini, F., De Nardis, R., Visini, F., Barbano, M.S., 2007. Active thrusting as a possible seismogenic source in Sicily (sourthern Italy). Some Insights from Integrated Structural-Kinematic and Seismological Data. Tectonophysics 445, pp. 145-167. http://dx.doi.org/10.1016/j.tecto.2007.07.007.

Lentini, F., Carbone, S., Guarnieri, P., 2006. Collisional and postcollisional tectonics of the Apenninic-Maghrebian orogen (southern Italy). In: Dilek, Y., Pavlides, S. (Eds.), Postcollisional Tectonics and Magmatism in the Mediterranean Region and Asia. Special Paper - Geological Society of America 409, pp. 57-81. http://dx.doi.org/10.1130/ 2006.2409(04).

Lundgren, P., Berardino, P., Coltelli, M., Fornaro, G., Lanari, R., Puglisi, G., Sansosti, E., Tesauro, M., 2003. Coupled magma chamber inflation and sector collapse slip observed with synthetic aperture radar interferometry on Mt. Etna volcano. J. Geophys. Res. 108, 2247. http://dx.doi.org/10.1029/2001JB000657.

Marani, M.P., Gamberi, F., Bortoluzzi, G., Carrara, G., Ligi, M., Penitenti, D., 2004. Seafloor bathymetry of the Ionian Sea. In: Marani, M.P., Gamberi, F., Bonatti, E. (Eds.), From Seafloor to Deep Mantle: Architecture of the Tyrrhenian Backarc Basin: Mem. Descr. Carta Geol. It., v. 44. Plate 3, Roma, System Cart.

Masson, D.G., Watts, A.B., Gee, M.J.R., Urgeles, R., Mitchell, N.C., Le-Bas, T.P., Canals, M., 2002. Slope failures on the flanks of the western Canary Islands. Earth Sci. Rev. 57, 1-35. http://dx.doi.org/10.1016/S0012-8252(01)00069-1.

Moore, J.G., Clague, D.A., Holcomb, R.T., Lipman, P.W., Normark, W.R., Torresan, M.E., 1989. Prodigious submarine landslides on the Hawaiian Ridge. J. Geophys. Res. 94, $17,465-17,484$.

Morley, C.K., King, R., Hillis, R., Tingay, M., Backe, G., 2011. Deepwater fold and thrust belt classification, tectonics, structure and hydrocarbon prospectivity: a review. Earth Sci. Rev. 104, 41-91. http://dx.doi.org/10.1016/j.earscirev.2010.09.010.

Musumeci, C., Scarfi, L., Palano, M., Patanè, D., 2014. Foreland segmentation along an active convergent margin: new constraints in southeastern Sicily (Italy) from seismic and geodetic observations. Tectonophysics 630, 137-149. http://dx.doi.org/10.1016/ j.tecto.2014.05.017.

Nakamura, K., 1980. Who do long rift zones develop in Hawaiian volcanoes-a possible role of thick oceanic sediments. Bull. Volcanol. Soc. Japan 25, 255-269.

Neri, M., Acocella, V., Behncke, B., 2004. The role of the Pernicana Fault System in thespreading of Mt. Etna (Italy) during the 2002-2003 eruption. Bull. Volcanol. 66, 417-430. http://dx.doi.org/10.1007/s00445-003-0322-x.
Neri, M., Guglielmino, F., Rust, D., 2007. Flank instability on Mount Etna: radon, radar interferometry and geodetic data from the southern boundary of the unstable sector. J. Geophys. Res. 112. http://dx.doi.org/10.1029/2006JB004756.

Neri, M., Casu, F., Acocella, V., Solaro, G., Pepe, S., Berardino, P., Sansosti, E., Caltabiano, T. Lundgren, P., Lanari, E., 2009. Deformation and eruptions at Mt. Etna (Italy): a lesson from 15 years of observations. Geophys. Res. Lett. 36, L02309. http://dx.doi.org/10. 1029/2008GL036151.

Nicolich, R., Laigle, M., Hirn, A., Cernobori, L., Gallart, J., 2000. Crustal structure of the Ionian margin of Sicily: Etna volcano in the frame of regional evolution. Tectonophysics 329, 121-139. http://dx.doi.org/10.1016/S0040-1951(00)00192-X.

Nicolosi, I., D'Ajello Caracciolo, F., Branca, S., Ventura, G., Chiappini, M., 2014. Volcanic conduit migration over a basement landslide at Mount Etna (Italy). Sci. Rep. 4. http://dx. doi.org/10.1038/srep05293.

Pareschi, M.T., Boschi, E., Mazzarini, F., Favalli, M., 2006. Large submarine landslides offshore Mt. Etna. Geophys. Res. Lett. 33. http://dx.doi.org/10.1029/2006GL026064.

Peel, F.J., 2014. The engines of gravity-driven movement on passive margins: quantifying the relative contribution of spreading vs. gravity sliding mechanisms. Tectonophysics 633, 126-142. http://dx.doi.org/10.1016/j.tecto.2014.06.023.

Pino, N.A., Piatanesi, A., Valensise, G., Boschi, E., 2009. The 28 December 1908 MessinaStraits earthquake (Mw 7.1): a great earthquake throughout a century of seismology. Seismol. Res. Lett. 80, 243-259. http://dx.doi.org/10.1785/gssrl.80.2.243.

Polonia, A, Torelli, L, Gasperini, L., Mussoni, P. 2012. Active faults and historical earthquakes in the Messina Straits area (Ionian Sea). Nat. Hazards Earth Syst. Sci. 12, 2311-2328. http://dx.doi.org/10.5194/nhess-12-2311-2012.

Puglisi, G., Bonforte, A., Ferretti, A., Guglielmino, F., Palano, M., Prati, C., 2008. Dynamics of Mount Etna before, during, and after the July-August 2001 eruption inferred from GPS and differential synthetic aperture radar interferometry data. J. Geophys. Res. 113, B06405. http://dx.doi.org/10.1029/2006JB004811.

Rust, D., Kershaw, S., 2000. Holocene tectonic uplift patterns in northeastern Sicily: evidence from marine notches in coastal outcrops. Mar. Geol. 167, 105-126. http://dx. doi.org/10.1016/S0025-3227(00)00019-0.

van Wyk de Vries, B., Francis, P.W., 1997. Catastrophic collapse at stratovolcanoes induced by gradual volcano spreading. Nature 387, 387-390. http://dx.doi.org/10.1038/ $387387 \mathrm{a} 0$.

Wooller, L., van Wyk de Vries, B., Murray, J.B., Rymer, H., Meyer, S., 2004. Volcano spreading controlled by dipping substrata. Geology 32, 573. http://dx.doi.org/10.1130/ G20472.1. 